\title{
Bacteriological Investigation of Microorganisms (Salmonella sp. and Other Enterobacteriaceae) in Common Quails (Coturnix coturnix) Submitted to Different Forced-Molting Procedures
}

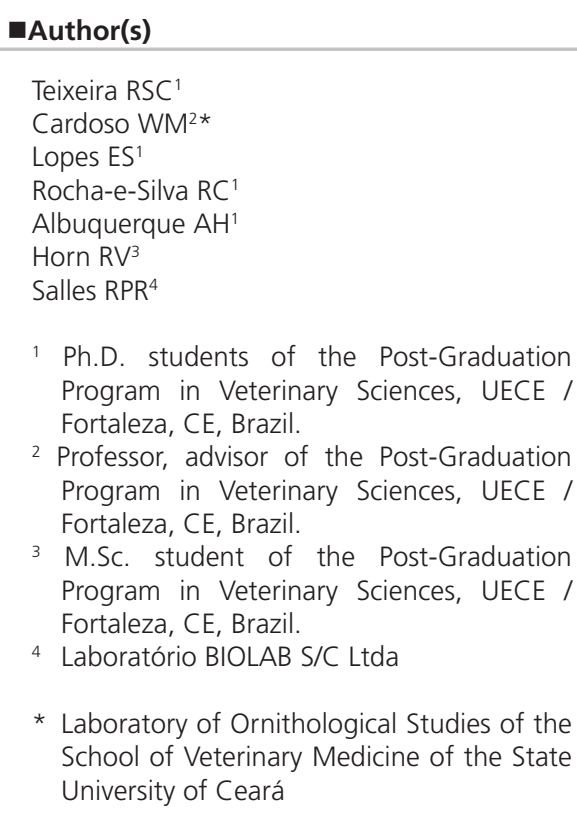

\section{Mail Adress}

Corresponding author e-mail address William Cardoso Maciel

Av.RogacianoLeite, 200, Aptº1303, BI.Tulipe, Bairro Salinas

CEP.60.810-000 Fortaleza - Ceará, Brazil

Phone:85 32411307 or 31019848 or 96549405

E-mail:william.maciel@uol.com.br

\section{Keywords}

Eggs, forced molting, zinc oxide, fasting, wheat midds diet.

\section{ABSTRACT}

The aim of this study was to investigate the presence of Salmonella in common quails submitted to forced molting. A total of 240 quails were divided at 40 weeks of age into four groups: CG (control, quails not submitted to molting); FM (fasting method); WM (fed wheat midds ad libitum); and ZM (zinc oxide method). From each group, 10 cloacal swabs, 10 fecal samples, and 20 egg samples were collected before molting (two weeks) and after molting (two weeks). The microbiological procedures for Salmonella spp. identification were performed in four steps. The agglutination test, using somatic and flagellar antigens, was used to confirm Salmonella-suspected colonies. According to the methodology applied, none of the samples was positive for Salmonella spp. The results showed that $20.0 \%$ of the egg samples from birds submitted to forced molting were contaminated with enterobacteria. It was concluded that, under the conditions of the present experiment, the stress caused by forced molting did not induce infection by Salmonella spp. or increased Enterobacteriaceae contamination levels in the eggs.

\section{INTRODUCTION}

Low egg quality is a common problem in the poultry industry and cause extensive losses. The main causes are related to environmental, health, and management issues (Cardoso et al., 2001). Among health factors, egg contamination by Salmonella spp. is extremely important in the poultry production chain (Hafez, 2005), because this genus is one of the main causes of food poisoning in humans (Chernaki-Lefferet al., 2002; Tirolli \& Costa, 2006).

Microorganisms may contaminate internal egg contamination by several pathways: through the ovary, when the agent remains inside the egg during its formation; through the uterus, when the agent is present in the oviduct epithelium or in the serosa of the air sacs; through the cloaca at the time of lay, when the egg may get in contact with contaminated feces; and through the external environment after lay, which is the most frequent form of microorganism invasion (Soncini \& Bittencourt, 2003).

Despite the significant role played by Salmonella spp. in food poisoning around the world and the economic losses caused in the poultry industry, other enterobacteria that may potentially cause foodborne diseases in humans should be considered, as several studies report their occurrence in eggs used for human consumption. The most frequent enterobacteria are Enterobacter sp., Klebsilella sp., Citrobacter sp., Serratia sp. Proteus sp., Pseudomonas sp., Hafnia and Providencia sp. (Adesiyunet al., 2006; Salles, 2007; Musgrove et al., 2008; Siqueira et al., 2008).
Submitted: July/2011

Approved: December/2012 
Teixeira RSC, Cardoso WM2, Lopes ES, Rocha-e-Silva RC, Albuquerque AH, Horn RV, Salles RPR

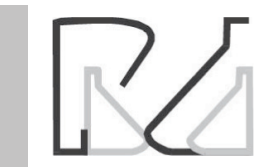

The main source of contamination of poultry products by food pathogens are animal feces (Rasmussen et al., 2004), particularly in the case of eggs. One of the most frequent forms of egg contact with feces is when birds present watery feces due to pathological (e.g., enteritis) or physiological conditions (e.g., changes in feed formulation), leading to egg contamination at the time of lay (Soncini \& Bittencourt, 2003).

In order to prevent bacterial contamination problems, good management practices need to be applied in egg production, providing hens proper health conditions that prevent the spread and replication of microorganisms. A common management practices applied in the egg industry is forced molting by fasting, aiming at obtaining a second laying cycle. However, this frequently affects hens' health. The stress caused by feed fasting results in an increase in blood corticosterone levels (Webster, 2003). It is known that stress hormones, such as corticosterone, have anti-inflammatory properties, thereby impairing the immune function (Golden et al., 2008). Therefore, molting induced by fasting increases hen susceptibility to several pathogenic microorganisms, including Salmonella (Holt, 2003).

Holt (2003) asserted that chickens submitted to forced molting are 100 to 1000 times more susceptible to Salmonella Enteritidis (SE) infection and may easily spread the bacterium to the non-infected hens in neighboring cages. This demonstrated that fasting to induce forced molting in commercial layers may eventually cause severe consumer health problems. This hypothesis was confirmed by Golden et al. (2008), who demonstrated that layers submitted to forced molting by feed fasting produced SE-contaminated eggs more frequently.

Despite these health issues involving the fasting method, forced molting has still been successfully used in commercial layer production. Alternative forced molting methods have been researched and used in poultry industry during the last decades to provide animal welfare and to prevent health problems. Among the employed methods, the supply of high dietary zinc levels is the most frequently studied and applied in the field, particularly in the United States (Mesquita Filho, 2008). Forced-molting methods using wheat-based feeds have also shown good results (Biggs et al., 2004; Dalanezi, 2007).

Forced molting is still not commonly applied in quail egg production (Garcia et al., 2001), although a few published studies have reported its effects on production and physiological aspects (Zamprônio et
Bacteriological Investigation of Microorganisms (Salmonella sp. and Other Enterobacteriaceae) in Common Quails (Coturnix coturnix) Submitted to Different Forced-Molting Procedures

al., 1996; Garcia et al., 2002.; Teixeira et al., 2007; Mesquita Filho, 2008; Faitarone et al., 2008). Scientific data on the effects of forced molting on quail health are lacking. Therefore, the objective of the present study was to evaluate the effect of different forced molting methods on the presence of Salmonella spp. in the eggs, feces, and cloacal swabs of common quails (Coturnix coturnix)

\section{MATERIALS AND METHODS}

\section{Molting methods}

In this experiment, 240 common quails at the end of their production cycle (40 weeks old) were used. Three forced molting methods were used: wheat method (WM), zinc oxide method (ZM), and fasting method (FM). The control group (CG) was composed of quails that were not induced to molting and were offered a commercial laying feed (Table 01) and water ad libitum during the entire experimental period.In

Table 1 - Ingredient composition and nutritional levels of the feed supplied to the experimental quails.

\begin{tabular}{|c|c|}
\hline Ingredients & Percentage \\
\hline Ground corn $8 \%$ & 46 \\
\hline Soybean meal $45.5 \%$ & 25 \\
\hline Semi-defatted soybeans $10 \% \mathrm{EE}$ & 19 \\
\hline Dicalcium phosphate $45 \%$ & 1.8 \\
\hline Limestone $38 \%$ & 7.3 \\
\hline Salt & 0.3 \\
\hline DL-Methionine $99 \%$ & 0.17 \\
\hline L-Lysine 78\% & 0.1 \\
\hline Mineral supplement1 & 0.13 \\
\hline Vitamin supplement2 & 0.2 \\
\hline Total & 100 \\
\hline \multicolumn{2}{|l|}{ Composition } \\
\hline Crude protein (\%) & 21.985 \\
\hline AME (kcal/kg) & 2807 \\
\hline Calcium & 3.320 \\
\hline Available phosphorus & 0.693 \\
\hline Methionine + cystine (\%) & 0.78 \\
\hline Lysine (\%) & 1.10 \\
\hline Methionine (\%) & 0.43 \\
\hline \multicolumn{2}{|c|}{$\begin{array}{l}\text { 1. Mineral supplement (per kg product):Cu.10,000 mg; Fe.100,000 mg; I, 1,500 mg, } \\
\text { Mn, 150,000 mg; Zn, 100,000 mg. } \\
\text { 2. Vitamin supplement (per } \mathrm{kg} \text { product):Vitamin A, 12,000,000 IU; Vitamin D3, } \\
\text { 3,600,000 IU; Vitamin K, 1,600 mg; Vitamin B1, 2,500 mg; Vitamin B12 - 12,500 } \\
\text { mg; niacin - 3,750 mg; pantothenic acid - 12,500mg; folic acid -15,000 mg; antio- } \\
\text { xidant - 25,000mg. }\end{array}$} \\
\hline
\end{tabular}


Teixeira RSC, Cardoso WM2, Lopes ES, Rocha-e-Silva RC, Albuquerque AH, Horn RV, Salles RPR
Bacteriological Investigation of Microorganisms (Salmonella sp. and Other Enterobacteriaceae) in Common Quails (Coturnix coturnix) Submitted to Different Forced-Molting Procedures total, 60 birds were designated to each experimental group (WM, ZM, FM, CG). Birds were weighed and housed in conventional pyramid-type cages (64 birds/ $\mathrm{m}^{2}$ ) belonging to the experimental houses of the School of Veterinary Medicine of the State University of Ceará, Brazil.

Molting was induced in WM and ZM quails by feeding wheat midds and a laying feed containing 25000 ppm zinc oxide, respectively. FM birds were submitted to complete feed fasting until the end of the treatment. Independently of treatment group, all birds were offered water ad libitum. Birds were submitted to the treatments until the body weight loss (BWL) specific for each method was achieved, as follows: WM (25\% BWL), and ZM and FM (30\% BWL).

\section{Microbiological evaluation and sample collection}

The microbiological evaluation consisted in the investigation of the presence of Salmonella spp. in cloacal swabs, fresh fecal samples, and eggs two weeks before and two weeks after quails were submitted to forced molting. The same procedure was applied to investigate the presence of other Enterobacteriaceae in egg samples. Ten fecal samples and ten cloacal swabs (pool of three birds) were collected from each experimental group. Twenty egg samples, consisting of two eggs each, were evaluated.

\section{Microbiological procedures}

Cloacal swabs and fresh fecal samples (1g) were collected, transported to the Ornithological Studies Lab and immediately processed. Eggshells were disinfected by immersion in ethanol at $70 \%$, and then broken. Egg content was homogenized by agitation in glass flasks, and 1-mL aliquots were used as sample unit. Enterobacteria isolation and identification were performed according to the following steps: Pre-enrichment, selective enrichment, plating and presumptive identification, biochemical tests, serology, and typification. During the pre-enrichment phase, $10 \mathrm{~mL}$ buffered peptone water at $1 \%$ were added to the collected clocal swab, fecal, and egg samples. In selective enrichment, $0.1 \mathrm{~mL}$ and $1 \mathrm{~mL}$ aliquots of the pre-enriched culture were transferred to tubes containing $10 \mathrm{~mL}$ Rappaport-Vassiliadis broth and $10 \mathrm{~mL}$ selenite cystine broth, respectively. Samples were then transferred to selective liquid media, using a platinum loop, to plates containing the selectiveindicator media brilliant green agar and MacConkey agar to perform the presumptive identification. Colonies with morphological characteristics suggesting Salmonella spp. were inoculated in tubes with TSI (triple sugar iron) agar slant, LIA (lysine iron agar) slant, and SIM (sulfide-indole-motility) agar. Colonies were biochemically characterized by glucose and sucrose fermentation properties, gas production, $\mathrm{H}_{2} \mathrm{~S}$ production, indole production, and motility. All tests were carried out at $37{ }^{\circ} \mathrm{C}$ incubation temperature for $24 \mathrm{~h}$. Colonies biochemically identified as Salmonella spp. were submitted to serology, using rapid plate seroagglutination tests with the use of flagellar $(\mathrm{H})$ and somatic (O) antisera.

The absolute frequency of Enterobacteriaceae was determined using the plating results of isolates suspected of Salmonella. The isolation of bacteria not belonging to the family Enterobacteriaceae were not considered in the study. The Chi-square test at 5\% significance level was used to compare the numbers of egg samples contaminated with Enterobacteriaceae among treatments before and after forced molting was implemented.

\section{RESULTS AND DISCUSSION}

The microbiological procedures did not detect the presence of Salmonella spp. in none of the egg, fecal, or cloacal swab samples collected from all evaluated experimental groups. Despite the absence of Salmonella determined in the present study, several other authors demonstrated that laying hens submitted to forced molting by the method of feed fasting are more susceptible to this microorganism (Holt \& Porter, 1992; Macriet al., 1997; Berchieri Jr., 2000; Holt, 2003; Berry, 2003). This was clearly shown in the study of Holt et al. (1995). The authors induced molting in commercial layers using fasting and orally infected these birds after four days with SE $\left(5-10 \times 10^{6}\right)$. They observed 24 and 96 hours after the experimental infection significantly higher SE counts in the colon, ceca, and feces in the molted birds compared with the hens not submitted to forced molting. In the ileum, SE counts were higher only $48 \mathrm{~h}$ after the experimental infection. Nakamura et al. (2004) observed that layers submitted to forced molting by fasting shed more Salmonella in the feces until day 14 post-infection than the control birds. As to Salmonella shedding in the eggs, Golden et al. (2008) observed that layers submitted to fasting may produce SE-contaminated eggs more frequently than fed layers; however, shedding declines with time. 
Teixeira RSC, Cardoso WM2, Lopes ES, Rocha-e-Silva RC, Albuquerque AH, Horn RV, Salles RPR

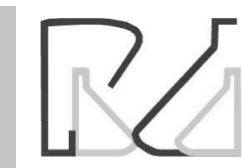

Salmonella isolation has also been reported in layers submitted to molting using alternative methods. McReynolds et al. (2006) found that alternative molting methods usually result in low Salmonella incidence and significantly reduce total bacterial counts in the ceca and other internal organs in layers submitted to forced molting and challenged with Salmonella Enteritidis. Therefore, the authors stress that alternative forced molting methods do not completely eliminate the possible risk of Salmonella infection.

Most studies involving Salmonella isolation in laying chickens submitted to forced molting used an inoculation procedure to evaluate bird sensitivity to that microorganism. In the present study, quails were not inoculated with Salmonella, which may explain why its presence was not detected. However, some studies in literature show the isolation of Salmonella spp in layers submitted to forced molting using epidemiological investigation. Garber et al. (2003) surveyed farms in 15 US states using fecal matter swabs collected in layers houses with different environments. The researchers observed that layers submitted to forced molting had more probability of being positive for Salmonella enterica serotype Enteritidis than contemporary layers not submitted to molting. Souza et al. (2002) performed an epidemiological survey on the incidence
Bacteriological Investigation of Microorganisms (Salmonella sp. and Other Enterobacteriaceae) in Common Quails (Coturnix coturnix) Submitted to Different Forced-Molting Procedures

of Salmonella in layers submitted to forced molting and isolated Salmonella Give from cloacal and fecal samples before and 30 days after fasting. The authors detected the presence of that microorganism in samples of meat meal and feed supplied to the layers, and argued that the finding of the same serotypes in the birds indicated the intake of contaminated feed. Therefore, the presence or absence of Salmonella spp. in the environment where molting is induced may determine the spread of these bacteria. According to Hinton et al. (2000), fasting causes physical, chemical and microbiological changes in the bird's crop, and these changes may impair the natural capacity to inhibit the local colonization by Enterobacteriacea.

Table 2 shows the presumptive results relative to Enterobacteriacea isolated in quails submitted to forced molting by different methods.

There was no significant difference ( $p>0.05$ ) among treatments as to absolute frequencies of samples positive for Enterobacteriaceae before and after forced molting. The highest absolute frequency in contaminated egg samples was observed in the WM group post-molting (25\%), whereas the lowest frequency was $10 \%(n=2)$ and it was observed in the CG and WM group before molting.

Table 2 - Frequency of Enterobacteriaceae isolated from the eggs of common quails submitted to forced molting by different methods

\begin{tabular}{|c|c|c|c|c|c|c|c|c|}
\hline \multirow{3}{*}{ Isolated Enterobacteriaceae } & \multicolumn{8}{|c|}{ Enterobacteriaceae frequency per treatment } \\
\hline & \multicolumn{3}{|c|}{ Before molting } & \multirow[b]{2}{*}{ ZM } & \multicolumn{4}{|c|}{ After molting } \\
\hline & $C G$ & FM & WM & & $C G$ & $\mathrm{FM}$ & WM & ZM \\
\hline$K+S$ & 1 & 1 & - & - & - & - & - & - \\
\hline$S$ & 1 & 1 & - & - & - & - & - & - \\
\hline$E$ & - & 1 & - & 1 & 2 & 2 & & 2 \\
\hline$E+K+S h$ & - & - & 1 & - & - & - & - & - \\
\hline Sh & - & - & 1 & - & - & - & - & 1 \\
\hline K & - & - & - & 1 & - & 1 & - & - \\
\hline$E+K+S+S h$ & - & - & - & 1 & - & - & - & - \\
\hline$E+K$ & - & - & - & 1 & - & - & 1 & - \\
\hline$P$ & - & - & - & - & 1 & - & - & - \\
\hline C & - & - & - & - & - & 1 & 3 & 1 \\
\hline $\mathrm{C}+\mathrm{E}+\mathrm{H}+\mathrm{S}$ & - & - & - & - & - & - & 1 & - \\
\hline Total & $2(10 \%)$ & $3(15 \%)$ & $2(10 \%)$ & $4(20 \%)$ & $3(15 \%)$ & $4(20 \%)$ & $5(25 \%)$ & $4(20 \%)$ \\
\hline
\end{tabular}

C = Citrobacter sp.; $E=$ Enterobacter; $P=$ Proteus sp.; $K=$ Klebsiella sp.; $S=$ Serratia sp.; $S h=$ Shigella sp.

$\mathrm{H}=$ Hafnia sp. 
Teixeira RSC, Cardoso WM2, Lopes ES, Rocha-e-Silva RC, Albuquerque AH, Horn RV, Salles RPR
Bacteriological Investigation of Microorganisms (Salmonella sp. and Other Enterobacteriaceae) in Common Quails (Coturnix coturnix) Submitted to Different Forced-Molting Procedures
The presumptive results found in the present study relative to absolute numbers and percentages of eggs contaminated with enterobacteria are similar or much lower than those reported in literature. This is demonstrated in the study of Stepien-Pyśniak (2010). The author qualitatively analyzed Gramnegative bacteria, particularly those belonging to Enterobacteriaceae family in the eggshell, yolk, and albumen of fresh eggs produced in large and small farms, and found that Escherichia coli, Enterobacter, Citrobacter, and Klebsiella were isolated more often in the eggshell, whereas in the albumen and in the yolk, Escherichia coli was more common. The least frequently isolated bacteria were Proteus and Serratia. Considering the total percentage of enterobacteria, Adesiyun et al. (2006) evaluated fresh eggs from Trinidad farms and found that $28.3 \%$ of the eggshells and $15.2 \%$ of the egg content were contaminated. Therefore, total egg contamination was higher than those found in quail eggs before or after forced molting. There are few studies on Enterobacteriaceae in quail eggs. However, in the metropolitan area of Fortaleza, CE, Brazil, Siqueira et al. (2008) carried out a study on the contamination of quail eggs by Enterobacteriaceae. The researchers found a significant contamination rate $(45.59 \%)$ in quail eggs collected in supermarkets - Enterobacter and Shigella were the most frequent agents - and attributed these results to possible hygiene issues along the quail egg production chain. Therefore, the lowest contamination rate found in quail eggs before or after forced molting may be explained by the fact that the eggs were evaluated immediately after lay, and not after processing and preservation steps in a supermarket shelf.

\section{CONCLUSIONS}

Under the conditions of the present experiment, no Salmonella spp. was detected in cloacal swab, fecal or egg samples neither before nor after molting induced by different methods (feed fasting, feed based on wheat midds, or feed with high zinc oxide level). Therefore, it was not possible to determine if forced molting had any influence on the presence of that pathogen. Further studies are required involving previously infected quails to understand this relationship better.

The results demonstrated that the amount of quail eggs contaminated by bacteria belonging to the family Enterobacteriaceae was low before and after molting, and that this was not influenced by the evaluated forced molting methods.

\section{ACKNOWLEDGEMENTS}

The authors express their gratitude for the support given by Conselho Nacional de Desenvolvimento Científico e Tecnológico (CNPq) and Fundação Cearense de Apoio ao Desenvolvimento Científico e Tecnológico (FUNCAP).

\section{REFERENCES}

Adesiyun A, Offiah N, Seepersadsingh N, Rodrigo S, Lashley V, Musai L. Frequency and antimicrobial resistance of enteric bacteria with spoil age potential isolated from table eggs. Food Research International 2006;9(2):212-219.

Berchieri Júnior A. Salmoneloses aviárias. In: Berchieri Júnior A, Macari M, editors. Doenças das aves. Campinas: FACTA; 2000. p.185-195.

Berry WD. The physiology of induced molting. Poultry Science 2003;82(6):971-980.

Biggs PE, Persia ME, Koelkebeck KW, Parsons C. Further evaluation of nonfeed removal methods for molting programs. Poultry Science 2004;83(5):745-752.

Cardoso ALSP, Tessari ENC, Castro AGM, Kanashiro AMI, Gama NMSQ. Pesquisa de coliformes totais e coliformes fecais analisados em ovos comerciais no laboratório de patologia avícola de Descalvado. Arquivo do Instituto Biológico 2001;68(1):19-22.

Chernaki-Leffer AM, Biesdorf SM, Almeida LM, Leffer EVB, Vigne F. Isolamento de enterobactérias em Alphitobius diaperinus e na cama de aviários no oeste do estado do Paraná, Brasil. Brazilian Journal of Poultry Science 2002;4(3):243-247.

Dalanezi JA. Produção e qualidade dos ovos de poedeiras comerciais submetidas a programas de muda forçada. Tese de Doutorado em Zootecnia, Faculdade de Medicina Veterinária e Zootecnia [thesis]. Botucatu (SP): Universidade Estadual Paulista; 2007.

Faitarone ABG, Garcia EA, Pizzolante CC, Molino AB, Pelícia K, Berto D. Forced-molting methods and their effects on the performance and egg quality of japanese quails (Coturnix japonica) in the second laying cycle. Brazilian Journal Poultry Science 2008;10(1):53-57.

Garber L, Smeltzer M, Fedorka-Cray P, Ladely S, Ferris K. Salmonella enterica serotype Enteritidis intableegglayerhouse environments and in micein US layer houses and associated factors. Avian Disease 2003;47(1):134-142.

Garcia EA, Mendes AA, Pizzolante CC. Performance of layer quail fed corn meal or layer diet during a post molt period. Brazilian Journal of Poultry Science $2002 ; 4(2): 119-124$

Golden NJ, Marks HH, Coleman ME., Schroeder CM, Bauer Jr. NE, Schlossera WD. Review of induced molting by feed removal and contamination of eggs with Salmonella enterica serovar Enteritidis. Veterinary Microbiolology 2008;131(3-4):215-228.

Hafez HM. Governmental regulations and concept behind eradication and control of some important poultry diseases. World's Poultry Science Journal 2005;61:569-581

Hinton A, Buhr RJ, Ingram KD. Physical, chemical, and microbiological changes in the crop of broiler chickens subjected to incremental feed withdrawal. Poultry Science 2000;79(2):212-218.

Holt PS; Porter Jr RE. Effect of induced molting on the course of infection and transmission of Salmonella enteritidis in white Leghorn hens of different ages. Poultry Science 1992; 71(11):1842-1848. 
Holt PS, Macri MP, Porter Jr R.E. Microbiological analysis of the early Salmonella enteritidis infection in molted and unmolted hens. Avian Disease 1995;39(1):55-63.

Holt PS. Molting and Salmonella enterica serovar enteritidis infection: the problem and some solutions. Poultry Science 2003;82(5):1008-1010.

Macri NP, Porter Jr RE, Holt PS. The effects of induced molting on the severity of acute intestinal inflammation caused by Salmonella enteritidis. Avian Disease 1997;41(1):117-124

McReynolds JL, Moore RW, Kubena LF, Byrd JA, Woodward CL, Nisbet DJ, Ricke SC. Effect of various combinations of alfalfa and standard layer diet on susceptibility of laying hens to Salmonella Enteritidis during forced molt. Poultry Science 2006; 85(7): 1123-1128.

Mesquita Filho RM. Avaliação do método de muda sobre o desempenho produtivo para codornas japonesas [dissertation]. Viçosa (MG):Universidade Federal de Viçosa; 2008

Musgrove WT, Northcutt JK, Jones DR, Cox NA, Harrison MA. Enterobacteriaceae and related organisms isolated from shell eggs collected during commercial processing. Poultry Science 2008; 87(6):1211-1218.

Nakamura M, Nagata T, Okamura S, Takehara K, Holt PS. The effect of killed Salmonella Enteritidis vaccine prior to induced molting on the shedding of Salmonella Enteritidis in laying hens. Avian Disease 2004;48(1):183188.

Rasmussen MA, Casey T, Petrich JW. Meat carcass inspection using the fluorescence of dietary porphyrins. Joint Annual Meeting of the American Dairy Science Association. Poultry Science Association 2004;82:166

Salles RPR. Pesquisa de Salmonella spp. em galinhas poedeiras e Enterobactérias em ovos comerciais da Região Metropolitana de Fortaleza [thesis]. Fortaleza (CE): Universidade Estadual do Ceará; 2007.
Siqueira AA, Cardoso WM, Silva EE, Romão JM, Nogueira CG, Andrade JDM, Castro SB, Teixeira RSC. Identificação de enterobactérias em ovos de codornizes japonesas (Coturnix japonica) na Região Metropolitana de Fortaleza - Ce, Brasil. Revista Portuguesa de Ciências Veterinárias 2008; 107(565-566):78-82.

Soncini RA, Bittencourt FL. Contaminação dos ovos após a postura. In: Macari M, Gonzales E, editor. Manejo da incubação. Jaboticabal: FACTA; 2003. p.437-453.

Souza ERN, Carvalho EP, Dionizio FL. Estudo da presença de Salmonella sp em poedeiras submetidas a muda forçada. Ciência e Agrotecnologia 2002;26(1):140-147.

Stępień-Pyśniak D. Occurrence of Gram-negative bacteria in hens' eggs depending on their source and storage conditions. Polish Journal of Veterinary Sciences 2010;13(3):507-513.

Teixeira RSC, Cardoso WM, Nogueira CG, Câmara SR, Romao JM, Siqueira AA, Sampaio FAC, Moraes TGV, Campello CC; Buxade CC. Evaluation of induced molt methods on viability and reproductive system regression in Japanese quails (Coturnix japonica). Brazilian Journal of Poultry Science 2007;9(2):85-89.

Tirolli ICC, Costa CA. Ocorrência de Salmonella spp. em carcaças de frangos recém abatidos em feiras e mercados da cidade de ManausAM. Revista Acta Amazonica 2006:36(2):205-208.

Webster AB. Physiology and behavior of the hen during induced molt. Poultry Science 2003;82(6): 992-1002.

Zamprônio EC, Moraes VMB, Malheiros RD. Efeitos da muda forçada sobre o desempenho produtivo e qualidade dos ovos em codornas (Coturnix coturnix japonica). Conferência APINCO de Ciência e Tecnologia Avícolas; 1996; Curitiba, Paraná. Brasil. p.12. 